Disclosure of Interests: Kevser Gok: None declared, Kemal Nas: None declared, Erkan Kilic: None declared, Betul Sargin: None declared, Sevtap Acer Kasman: None declared, Hakan Alkan: None declared, Nilay Sahin: None declared, Gizem Cengiz: None declared, Nihan Cuzdan: None declared, Ilknur Albayrak Gezer: None declared, Dilek Keskin: None declared, Cevriye Mülkoğlu: None declared, Hatice Resorku: None declared, İsmihan Sunar: None declared, Ajda Bal Hasturk: None declared, Mehmet Tuncay Duruöz Grant/research support from: Abvie, Speakers bureau: Novartis, AMGEN, Abdi İbrahim, İlko, Okan Kucukakkas: None declared, Ozan Volkan Yurdakul: None declared, Meltem Alkan Melikoglu: None declared, Yildiray Aydin: None declared, Figen Ayhan: None declared, Hatice Bodur: None declared, Mustafa Calis: None declared, Erhan Capkin: None declared, Gul Devrimsel: None declared, SAMI HIZMETLI: None declared, Ayhan Kamanli: None declared, Yasar Keskin: None declared, Hilal Kocabas: None declared, Oznur Kutluk: None declared, Nesrin Şen: None declared, Omer Faruk Sendur: None declared, ibrahim tekeoğlu: None declared, Murat Toprak: None declared, Sena Tolu: None declared, Tiraje Tuncer: None declared DOI: 10.1136/annrheumdis-2019-eular.8027

\section{SAT0395 RESPONSIVENESS AND CLINICAL TRIAL DISCRIMINATION OF SWOLLEN AND TENDER JOINT COUNTS FOR THE MEASUREMENT OF MSK DISEASE ACTIVITY IN PSORIATIC ARTHRITIS}

Ali Duarte-Garcia ${ }^{1}$, Lihi Eder ${ }^{2}$, Niti Goel ${ }^{3}$, Maarten de Wit ${ }^{4}$, Dafna D. Gladman ${ }^{5}$, Oliver Fitzgerald ${ }^{6}$, Philip J. Mease ${ }^{7}$, Ying Ying Leung ${ }^{8}$, Ana-Maria Orbai ${ }^{9}$, Bev Shea ${ }^{10}$, Vibeke Strand ${ }^{11}$, Philip Helliwell ${ }^{12}$, Alisa Stephens-Shields ${ }^{13}$, William Tillett ${ }^{14}$, Laura C. Coates ${ }^{15}$, Alexis Ogdie ${ }^{13}$, GRAPPA-OMERACT Psoriatic Arthritis Working Group. ${ }^{1}$ Mayo Clinic, Rochester, MN, United States of America; ${ }^{2}$ Women's College, University of Toronto, Toronto, ON, Canada; ${ }^{3}$ Patient Research Partner, Durham, NC, United States of America; ${ }^{4}$ Patient Research Partner, Amsterdam, Netherlands: ${ }^{5}$ Toronto Western, University of Toronto, Toronto, ON, Canada; ${ }^{6}$ 7St Vincent's University Hospital and Conway Institute for Biomolecular Research, University College, Dublin, Ireland; ${ }^{7}$ Swedish Medical Center/ Providence-St. Joseph's Health and University of Washington, Seattle, WA, United States of America; ${ }^{8}$ Singapore General Hospital, Singapore, Singapore; ' Johns Hopkins University, Baltimore, MD, United States of America; ${ }^{10}$ University of Ottawa, Ottawa, Canada; ${ }^{11}$ Stanford University, Palo Alto, United States of America; ${ }^{12}$ University of Leeds, Leeds, United Kingdom; ${ }^{13}$ University of Pennsylvania, Philadelphia, PA, United States of America; ${ }^{14}$ Royal National Hospital for Rheumatic Diseases and the University of Bath, Bath. United Kingdom; ${ }^{15}$ University of Oxford, Oxford, United Kingdom

Background: While tender and swollen joint counts (TJC and SJC) are key instruments for the assessment of peripheral arthritis in PsA, little is known about the psychometric properties of TJC and SJC in randomized controlled trials (RCTs) and how these properties differ among patient subgroups.

Objectives: To assess the responsiveness and discrimination of TJC and SJC in PsA using RCT datasets and evaluate subgroups of patients with early vs. established disease and 3 or less vs 4 or more active joints. Methods: Patient-level data from 8 phase III RCTs and the Tlght COntrol of Psoriatic Arthritis (TICOPA) trial were analyzed ${ }^{2}$. The standardized response mean (SRM, mean difference between baseline and follow up divided by the standard deviation (SD) of the mean difference) and standardized mean differences (SMD, mean difference in the treated group minus the mean difference in the placebo group divided by the pooled SD for the change) were used to address responsiveness and discrimination respectively. TJC28, SJC28, TJC68, and SJC66 were the primary measures of interest but physician and patient global assessments (PhGA and PtGA) and pain were included for comparison. SRMs

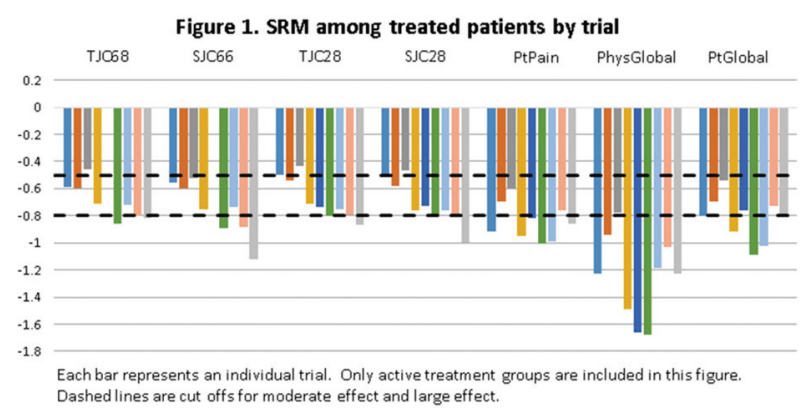

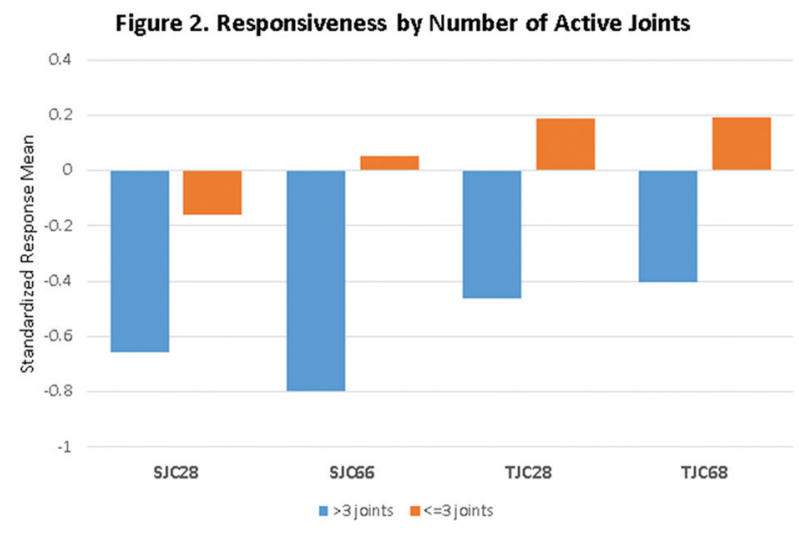

were calculated in subgroups of patients with less than 3 (TJC68/SJC66 $\leq 3$ ) or more than 3 (TJC68/SJC66) active joints as well as early $<2$ years) and established ( $\geq 2$ years) disease.

Results: In traditional phase III RCTs, TJC and SJC were responsive and had good clinical trial discrimination. SRMs were similar and ranged from -0.8 to -0.4 ('moderate' responsiveness) (Figure 1). SMDs were similar among SJC28 and SJC66 and likewise between TJC28 and TJC68 but mostly within the small effect range (-0.2 to -0.5 ; not shown). PhGA and PtGA had higher SMDs than the joint counts. SRMs were substantially lower for joint counts (and also PtGA) among the low compared with the higher joint count groups (Figure 2). There were no substantial differences in SRMs between patients with early and established disease. Conclusion: Joint counts are responsive to change and have reasonable discrimination in RCTs among patients higher disease activity at baseline. However, joint counts may not be ideal outcome measures in oligoarticu lar disease and have lower responsiveness and discrimination in this subgroup.

\section{REFERENCES}

[1] Duarte-Garcia et al. J Rheumatol 2019 In Press.

[2] Coates et al. Lancet 2016

Acknowledgement: Funded by the Rheumatology Research Foundation; We would like to thank Janssen Scientific Affairs LLC, YODA (Yale Open Data Access) Project, UCB, Novartis, and Pfizer for their scientific partnership.

Disclosure of Interests: Ali Duarte-Garcia: None declared, Lihi Eder Grant/research support from: AbbVie, Eli Lilly and Company, Amgen, Celgene, UCB, Janssen, Novartis, and Pfizer, Consultant for: AbbVie, Eli Lilly and Company, Amgen, Celgene, UCB, Janssen, Novartis, and Pfizer, Niti Goel Shareholder of: Own stock options in Kezar Life Sciences. Employee of: Corporate officer of Kezar Life Sciences., Maarten de Wit: None declared, Dafna D Gladman Grant/research support from: AbbVie, Amgen, Celgene, Lilly, Novartis, Pfizer, and UCB, Consultant for: AbbVie, Amgen, BMS, Celgene, Galapagos, Gilead, Janssen, Lilly, Novartis, Pfizer and UCB, Oliver FitzGerald: None declared, Philip J Mease Grant/ research support from: AbbVie, Amgen, BMS, Celgene, Janssen, Lilly, Novartis, Pfizer, SUN and UCB, Consultant for: AbbVie, Amgen, BMS Galapagos, Gilead Sciences, Inc., Janssen, Lilly, Novartis, Pfizer, SUN and UCB, Speakers bureau: AbbVie, Amgen, BMS, Celgene, Genentech, Janssen, Lilly, Novartis, Pfizer and UCB, Ying Ying Leung Grant/research support from: Abbvie, Novartis, Speakers bureau: Abbvie and Novartis, Speakers bureau: Novartis, Ana-Maria Orbai Grant/research support from: AbbVie, Celgene, Horizon Pharma, Janssen, Lilly, and Novartis, Consultant for: Lilly, Janssen, Novartis, Pfizer, and UCB, Bev Shea Employee of: Salary partially paid by OMERACT, Vibeke Strand Consultant for: AbbVie, Amgen, Bayer, BMS, Boehringer Ingelheim, Celgene, Celltrion, CORRONA, Crescendo, EMD Serono, Genentech/Roche, GSK, Horizon, Inmedix, Janssen, Kezar, Lilly, Merck, Novartis, Pfizer, Regeneron, Samsung, Sandoz, Sanofi, Servier, UCB., Philip Helliwell Grant/research support from: Paid to charity: from AbbVie, Janssen and Novartis, Consultan for: Paid to charity: from AbbVie, Amgen, Pfizer, and UCB and Celgene. Paid to self: from Celgene and Galapagos, Alisa Stephens-Shields: None declared, William Tillett Grant/research support from: AbbVie, Celgene, and Lilly, Consultant for: AbbVie, Celgene, Lilly, Novartis, and Pfizer Speakers bureau: Abbvie, Celgene, Lilly, Janssen, Novartis, UCB, and Pfizer, Laura C Coates Grant/research support from: AbbVie, Celgene, Lilly, Novartis and Pfizer, Consultant for: AbbVie, Amgen, BMS, Celgene, Galapagos, Gilead Sciences Inc., Janssen, Lilly, Novartis, Pfizer, Prothena Corp and UCB, Alexis Ogdie Grant/research support from: (To my university) Novartis, Pfizer, Grant/research support from: Novartis, Pfizer, Grant/ 
research support from: Novartis, Pfizer, Grant/research support from: Novartis, Pfizer, Consultant for: AbbVie, Bristol-Myers Squibb, Celgene, Corrona, Eli Lilly and Company, Novartis, Pfizer, and Takeda, Consultant for: AbbVie, Amgen, Bristol-Myers Squibb, Celgene, Corrona, Eli Lilly, Novartis, Pfizer Inc, Takeda, Consultant for: Abbvie, Amgen, BMS, Celgene, Corrona, Lilly, Novartis, Pfizer, Takeda, Consultant for: Abbvie, Amgen, BMS, Celgene, Corrona, Lilly, Novartis, Pfizer, Takeda DOI: 10.1136/annrheumdis-2019-eular.1659

\section{SAT0396 IMPROVEMENT IN THE SIGNS AND SYMPTOMS OF PSORIATIC ARTHRITIS WITH IXEKIZUMAB COMPARED TO PLACEBO IN PATIENT SUBGROUPS DEFINED BY BASELINE DISEASE CHARACTERISTICS}

Hans-Peter Tony ${ }^{1}$, Eva Galindez ${ }^{2}$, Aubrey Trevelin Sprabery ${ }^{3}$, Amanda M. Gellett ${ }^{3}$ Chen-Yen Lin ${ }^{3}$, So Young Park ${ }^{3}$, Clinton C. Bertram ${ }^{3}$, Alexis Ogdie ${ }^{4} .{ }^{1}$ University Hospital of Würzburg, Würzburg, Germany, ${ }^{2}$ Hospital de Basurto, Billbao, Spain; ${ }^{3}$ Eli Lilly and Company, Indianapolis, United States of America; ${ }^{4}$ Penn Medicine, Philadelphia, United States of America

Background: Ixekizumab (IXE), a high-affinity monoclonal antibody that selectively targets interleukin-17A, was superior to placebo (PBO) in two randomized Phase 3 studies in patients (pts) with active psoriatic arthritis (PsA). ${ }^{1,2}$

Objectives: To assess the consistency of response of IXE across subgroups of pts defined by specific baseline disease characteristics.

Methods: Data were analyzed from an integrated database of 2 randomized, double-blind, Phase 3 studies in pts who were either biologic Disease Modifying Anti-Rheumatic Drug (bDMARD)-naïve (SPIRIT-P1) or who had prior inadequate response or intolerance to TNF inhibitors (SPIRITP2). Analyses included pts randomly assigned to the approved dosing regimen of IXE (80 mg IXE every 4 wks [IXE Q4W] with a starting dose of $160 \mathrm{mg}$ IXE) or to PBO through Wk 24. Efficacy was measured as the percentage of pts achieving $\geq 20 \%, 50 \%$, or $70 \%$ improvement from baseline in the American College of Rheumatology criteria (ACR20/50/70) or minimal disease activity (MDA) in subgroups of pts defined by baseline presence of enthesitis, dactylitis, psoriasis body surface area (BSA) involvement $(<3 \%$ or $\geq 3 \%$ ), and c-reactive protein (CRP $>6$ or $\leq 6 \mathrm{mg} / \mathrm{L}$ ). Missing data were imputed by nonresponder imputation.

Results: Clinical response rates at Wk 24 in each subgroup are summarized (Table). Significantly $(p<0.05)$ more patients achieved ACR20, ACR50, ACR70, and MDA with IXE compared to placebo across patient subgroups defined by presence of enthesitis, presence of dactylitis, percentage of psoriasis BSA involvement, and by CRP levels at baseline. Conclusion: At Wk 24, IXE was superior to placebo for the treatment of PsA signs and symptoms regardless of baseline presence of dactylitis or enthesitis, BSA involvement, or CRP levels.

\section{REFERENCES}

[1] Mease, et al. Ann Rheum Dis. 2017

[2] Nash, et al. Lancet. 2017
Disclosure of Interests: Hans-Peter Tony Consultant for: Eli Lilly and Company, Speakers bureau: Eli Lilly and Company, Eva Galindez: None declared, Aubrey Trevelin Sprabery Shareholder of: Eli Lilly and Company, Employee of: Eli Lilly and Company, Amanda M. Gellett Shareholder of: Eli Lilly and Company, Employee of: Eli Lilly and Company, Chen-Yen Lin Shareholder of: Eli Lilly and Company, Employee of: El Lilly and Company, So Young Park Employee of: Eli Lilly and Company, Clinton C Bertram Shareholder of: Eli Lilly and Company, Employee of: Eli Lilly and Company, Alexis Ogdie Grant/research support from: (To my university) Novartis, Pfizer, Grant/research support from: Novartis, Pfizer, Grant/research support from: Novartis, Pfizer, Grant/research support from: Novartis, Pfizer, Consultant for: AbbVie, Bristol-Myers Squibb, Celgene, Corrona, Eli Lilly and Company, Novartis, Pfizer, and Takeda, Consultant for: AbbVie, Amgen, Bristol-Myers Squibb, Celgene, Corrona, Eli Lilly, Novartis, Pfizer Inc, Takeda, Consultant for: Abbvie, Amgen, BMS, Celgene, Corrona, Lilly, Novartis, Pfizer, Takeda, Consultant for: Abbvie, Amgen, BMS, Celgene, Corrona, Lilly, Novartis, Pfizer, Takeda

DOI: 10.1136/annrheumdis-2019-eular.1620

\section{SAT0397 DESCRIPTIVE COMPARISONS OF THE IMPACT OF APREMILAST AND METHOTREXATE MONOTHERAPY ON PATIENTS WITH OLIGOARTICULAR PSORIATIC ARTHRITIS IN THE CORRONA PSORIATIC ARTHRITIS/ SPONDYLOARTHRITIS REGISTRY}

Alexis Ogdie $^{1}$, Mei Liu ${ }^{2}$, Meghan Glynn², Kelechi Emeanuru², Leslie Harrold2,3, Sven Richter ${ }^{4}$, Benoit Guerette ${ }^{4}$, Philip J. Mease ${ }^{5}$. ${ }^{1}$ University of Pennsylvania, Philadelphia, United States of America; ${ }^{2}$ Corrona, LLC, Waltham, United States of America; ${ }^{3}$ University of Massachusetts Medical School, Worcester, United States of America; ${ }^{4}$ Celgene Corporation, Summit, United States of America; ${ }^{5}$ Swedish Medical Center and University of Washington School of Medicine, Seattle, United States of America

Background: Therapeutic effectiveness has rarely been studied in a subpopulation of patients with oligoarticular PsA.

Objectives: To examine baseline characteristics and 6-month clinical assessments of PsA patients with oligoarthritis ( $\leq 4$ swollen joints) who initiated apremilast (APR) or methotrexate (MTX) monotherapy in the Cor rona PsA/SpA Registry, a prospective, US-based, observational cohort study. Patients initiating bDMARD monotherapy were also examined as a point of reference.

Methods: Patients $\geq 18$ years of age with PsA and oligoarthritis in the registry who initiated APR, MTX or a bDMARD (reference group) monotherapy and had a 6-month follow-up visit between June 2014 and March 2018 were included. Descriptive statistics were calculated for patients' clinical characteristics and disease assessments at treatment initiation and at the 6-month follow-up visit.

Results: The analysis included 150 patients initiating therapy (APR: $n=34$; MTX: $n=15$; bDMARD: $n=101$ ). Among APR and MTX initiators $79 \%$ and $20 \%$ received at least 1 prior bDMARD, respectively. APR initiators, compared with MTX initiators, were younger (mean [SD]: 55.7 [12.6] vs. 61.5 [16.6] years), had longer disease duration (mean [SD]: 8.0 [6.7] vs. 5.4 [7.8] years), and had higher levels of disease activity

\begin{tabular}{|c|c|c|c|c|c|c|c|c|}
\hline \multicolumn{9}{|c|}{ Clinical responses at Week 24 in subgroups defined by baseline disease characteristics (NRI) } \\
\hline & & & & & & & & \\
\hline & $\begin{array}{c}\text { PBO } \\
(\mathrm{N}=224)\end{array}$ & $\begin{array}{c}\text { IXE Q4W } \\
(\mathrm{N}=229)\end{array}$ & $\begin{array}{c}\text { PBO } \\
\text { (N=224) }\end{array}$ & $\begin{array}{c}\text { IXE Q4W } \\
(\mathrm{N}=229)\end{array}$ & $\begin{array}{c}\text { PBO } \\
(\mathrm{N}=224)\end{array}$ & $\begin{array}{c}\text { IXE Q4W } \\
(\mathrm{N}=229)\end{array}$ & $\begin{array}{c}\text { PBO } \\
(\mathrm{N}=224)\end{array}$ & $\begin{array}{l}\text { IXE Q4W } \\
(\mathrm{N}=229)\end{array}$ \\
\hline $\begin{array}{l}\text { Enthesitis } \\
\text { Present }\end{array}$ & 29/142(20) & $\begin{array}{c}88 / 159 \\
(55) \dagger\end{array}$ & 12/142 (9) & $58 / 159(37) \dagger$ & $\begin{array}{c}2 / 142 \\
(1)\end{array}$ & $31 / 159(20) \dagger$ & $\begin{array}{c}6 / 142 \\
(4)\end{array}$ & $\begin{array}{c}41 / 159 \\
(26) \dagger\end{array}$ \\
\hline Enthesitis Absent & 26/81 (32) & $39 / 70(56) \div$ & 10/81 (12) & $28 / 70(40) \dagger$ & $\begin{array}{c}4 / 81 \\
(5)\end{array}$ & $21 / 70(30) \dagger$ & $14 / 81$ (17) & $\begin{array}{l}25 / 70 \\
(36)^{*}\end{array}$ \\
\hline Dactylitis Present & $12 / 59(20)$ & $55 / 92(60) \dagger$ & $\begin{array}{l}6 / 59 \\
(10)\end{array}$ & $38 / 92(41) \dagger$ & $\begin{array}{l}2 / 59 \\
(3)\end{array}$ & $24 / 92(26) \dagger$ & $\begin{array}{c}5 / 59 \\
(9)\end{array}$ & $\begin{array}{l}33 / 92 \\
(36) \dagger\end{array}$ \\
\hline Dactylitis Absent & 43/164 (26) & $72 / 137(53) \dagger$ & $16 / 164(10)$ & $48 / 137(35) \dagger$ & $\begin{array}{c}4 / 164 \\
(2)\end{array}$ & $28 / 137(20) \dagger$ & 15/164 (9) & $\begin{array}{c}33 / 137 \\
(24) \dagger\end{array}$ \\
\hline BSA $<3 \%$ & 20/85 (24) & $44 / 80(55) \dagger$ & $\begin{array}{c}8 / 85 \\
(9)\end{array}$ & $29 / 80(36) \dagger$ & $\begin{array}{c}2 / 85 \\
(2)\end{array}$ & $17 / 80(21) \dagger$ & $\begin{array}{c}6 / 85 \\
(7)\end{array}$ & $\begin{array}{l}21 / 80 \\
(26) !\end{array}$ \\
\hline $\mathrm{BSA} \geq 3 \%$ & 35/134 (26) & $77 / 141(55) \dagger$ & $14 / 134(10)$ & $55 / 141(39) \dagger$ & $\begin{array}{c}4 / 134 \\
(3)\end{array}$ & $34 / 141(24) \dagger$ & 13/134 (10) & $\begin{array}{c}42 / 141 \\
(30) \dagger\end{array}$ \\
\hline $\mathrm{CRP} \leq 6 \mathrm{mg} / \mathrm{L}$ & 29/100 (29) & $45 / 97(46)^{*}$ & $11 / 100(11)$ & $31 / 97(32) \dagger$ & $\begin{array}{l}2 / 100 \\
\text { (2) }\end{array}$ & $16 / 97(17) \dagger$ & $11 / 100(11)$ & $\begin{array}{l}25 / 97 \\
(26) !\end{array}$ \\
\hline $\mathrm{CRP}>6 \mathrm{mg} / \mathrm{L}$ & 26/122 (21) & $80 / 129(62) \dagger$ & 11/122 (9) & $54 / 129(42) \dagger$ & $\begin{array}{c}4 / 122 \\
\text { (3) }\end{array}$ & $36 / 129(28) \dagger$ & $\begin{array}{c}9 / 122 \\
(7)\end{array}$ & $\begin{array}{c}41 / 129 \\
(32) \dagger\end{array}$ \\
\hline
\end{tabular}

